\title{
Trophic planktonic dynamics in a tropical estuary, Gulf of Nicoya, Pacific coast of Costa Rica during El Niño 1997 event
}

\author{
Dinámica trófica planctónica en un estuario tropical, Golfo de Nicoya, costa Pacífica \\ de Costa Rica durante El Niño 1997
}

\section{Ernesto Brugnoli-Olivera ${ }^{1}$ and Alvaro Morales-Ramírez ${ }^{2}$}

\author{
${ }^{1}$ Sección Oceanología, Facultad de Ciencias, Universidad de la República. Iguá 4225, Montevideo, Uruguay \\ ${ }^{2}$ CIMAR y Escuela de Biología, Universidad de Costa Rica. P.O. Box 2060 San Pedro de Montes de Oca, Costa Rica \\ ebo@fcien.edu.uy
}

\begin{abstract}
Resumen.- Durante las épocas seca y lluviosa de 1997 se analizó la dinámica trófica del plancton en el Golfo de Nicoya, costa Pacífica de Costa Rica. En dos profundidades de penetración de luz se determinaron la temperatura del agua, salinidad y oxígeno disuelto. En cada profundidad se cuantificaron los nutrientes inorgánicos, biomasa fitoplanctónica total y nanofitoplanctónica, recolectándose muestras para análisis taxonómicos fitoplanctónicos. Se realizaron arrastres oblicuos para estimar abundancias, composición y peso seco del zooplancton. La estimación indirecta de la tasa de herbivoría se realizó utilizando el presupuesto de pigmentos. El estudio coincidió con la ocurrencia de un evento El Niño reflejado en cambios de las características físico-químicas del agua en la zona de Punta Morales. La concentración de algunos nutrientes mostró una correlación con la salinidad y se encontraron diferencias significativas entre las épocas transición y lluviosa en las biomasas fitoplanctónicas. Se identificó un total de 43 taxa fitoplanctónicos, donde flagelados, diatomeas céntricas y pennadas representaron el $90 \%$ de la abundancia. Los copépodos fueron el grupo zooplanctónico más abundante y Acartia lilljeborgii, Pseudodiaptomus sp. у Paracalanus parvus, los herbívoros dominantes; los valores del peso seco de herbívoros varió entre 0,6 y $50 \mathrm{mg} \mathrm{m}^{-3}$. La tasa de herbivoría mostró un promedio de $0,67 \pm 0,83 \mathrm{~d}^{-1}$. Se encontró un comportamiento estacional con cambios en las concentraciones de nutrientes, disponibilidad del fitoplancton e incremento de las temperaturas, donde la predación y presión de herbivoría ocasionaron cambios en la estructura de las poblaciones planctónicas en la zona interna del Golfo de Nicoya.
\end{abstract}

Palabras clave: Plancton, tasa de herbivoría, Océano Pacífico

\section{Introduction}

Food webs in general show the transfer of energy and organic materials through various trophic levels of marine organisms (Lalli \& Parsons 1997). A simplified food chain might be composed of three levels, which includes

\begin{abstract}
The trophic dynamics of the plankton from the Gulf of Nicoya, a tropical estuary in the Pacific coast of Costa Rica, was conducted during dry and rainy seasons of 1997. Water temperature, oxygen and salinity were measured at two different light penetration depths. Inorganic nutrients, total and nannophytoplanktonic chlorophyll $a$ were determined at each depth and additional samples were taken for phytoplankton taxonomic work. Oblique zooplankton hauls were done and abundance, composition and dry weight of zooplankton were determined. Indirect grazing rate estimate was calculated using the pigment budget. The study period coincided with an El Niño event detected in the Punta Morales zone and reflected by a change in the physico-chemical water characteristics. Some nutrient concentrations were correlated to the salinity, and significant differences were observed between the transition and rainy seasons in the phytoplankton biomass of the two fractions. A total of 43 phytoplankton taxa were identified and flagellates, centric and pennate diatoms represented $90 \%$ of the total phytoplankton abundance. In the zooplanktonic samples, copepods were the most abundant group and Acartia lilljeborgii, Pseudodiaptomus sp. and Paracalanus parvus were the dominant herbivores; dry weight mean values of herbivorous copepods were between 0.6 and $50 \mathrm{mg} \mathrm{m}^{-3}$. Grazing rate showed a mean of $0.67 \pm 0.83 \mathrm{~d}^{-1}$. This study showed a seasonal behavior with changes in nutrient concentrations, availability of phytoplankton and rising temperatures through El Niño. Predation and grazing pressure produced changes in the structure of plankton (phyto and zooplankton) populations in the internal zone of Gulf of Nicoya.
\end{abstract}

Key words: Plankton, grazing rate, Pacific Ocean

phytoplankton as primary producers, zooplankton as primary consumers and fishes as secondary consumers. This basic chain acquires more complexity when other levels are added, or when one of its components modifies its feeding behavior in response to those factors, creating what is called a food web, in which multiple and shifting 
interactions between organisms occur (Begon et al. 1988). In spite of the complexity of the trophic relationships between different plankton functional compartments, the estimation, direct or indirect, of the factors that regulate primary production is key to determine the matter and energy fluxes through the trophic webs of an ecosystem. Also, the grazing pressure (top down theory) or the nutrients availability in a particular system (bottom up theory) have been proposed as regulator factors of the primary production (Lenz 1992). Mesozooplankton, especially copepods, plays a fundamental role in pelagic food webs because is a trophic link between primary producers and higher consumers (Ikeda et al. 2001). They are known to have a significant impact over phytoplankton, where diatoms have been considered the main food for copepods and other zooplankton herbivorous organisms (Kleppel et al. 1991, Kleppel 1993), although its role in the nutrition of copepods is controversial (Ban et al. 1997, Irigoien et al. 2002, Paffenhöfer 2002, Ianora et al. 2004, Jones \& Flynn 2005). Measurements of herbivory impact on the primary production are controversial as some authors consider grazing by herbivorous species to be non significant for primary production ( $<5 \%$ of PP) (Morales et al. 1991, Dam et al. 1993); others have estimated grazing rates of primary production higher than 25\% (Sautour et al. 2000) or $40 \%$ (White \& Roman 1992, Lenz et al. 1993). Values around $25-30 \%$ are comparable to the revision made by Calbet (2001) who compared several grazing studies worldwide using different methods, giving an estimate value of $22,6 \%$ from the primary production consumed per day. A first step to obtain information for an adequate management of fisheries includes the evaluation of the trophic interactions into the first levels of the food web, also primary producers and herbivores. The methodology for determination of grazing rates in situ includes experiments in the laboratory or the use of allometric equations (Harris et al. 2000), as well as incubations experiments. A proper manageable solution is to work with biomarkers of the grazing process such as phytoplankton pigments and their degradation products. Chlorophyll $a$ and pheopigments are known as direct products of phytoplankton growth and zooplankton grazing activity respectively, (Welschmeyer \& Lorenzen 1985, Carpenter et al. 1986, Strom \& Welschmeyer 1991).

There are numerous descriptive studies on the Gulf of Nicoya, Costa Rica, however there is a lack of information about the plankton dynamic of the system, although it supports one of the most important fisheries of the country. Most of the studies about plankton in the Gulf of Nicoya, especially zooplankton studies, have been carried out to evaluate some ecological aspects about composition, distribution, biomass (Hossfeld 1996, Morales-Ramírez 1996, von Wangelin \& Wolff 1996, Brugnoli-Olivera et al. 2004), impact of El Niño (Morales-Ramírez \& Brugnoli-Olivera 2001) and biodiversity (Morales-Ramírez \& Vargas 1995, MoralesRamírez 2001). Some studies have determined seasonal patterns of the primary productivity of the Gulf of Nicoya, with particularly high productivity values (up to $1.69 \mathrm{gC}$ $\mathrm{m}^{2} \mathrm{~d}^{-1}$ ), becoming one of the most productive tropical systems in the word (Córdoba-Muñoz 1993, Gocke et al. 2001). Such productivity is dominated by micro nannophytoplankton (Hargraves \& Víquez 1985, Brugnoli-Olivera 1998).

The goal of this study is to obtain an evaluation of the planktonic dynamics (phyto and zooplankton) in the Gulf of Nicoya, Costa Rica. For this purpose, the biomass and composition of two planktonic communities were determined through dry and rainy seasons. Also, environmental factors (temperature, salinity, oxygen, inorganic nutrients) and indirectly estimating the grazing rate were measured.

\section{Material and methods}

\section{Study area}

The Gulf of Nicoya is a tropical estuary $\left(1543 \mathrm{~km}^{2}\right)$, located at the Pacific coast of Costa Rica $\left(10^{\circ} \mathrm{N} ; 85^{\circ} \mathrm{W}\right)$ (Fig. 1). According to Voorhis et al. (1983) two main regions may be identified: an external zone delimited to the south by the open ocean, and to the north by a line from San Lucas Island to Puntarenas peninsula; and a shallow internal zone which comprises the rest of the gulf. The external zone is bordered by a rocky coast with sandy beaches and its bottom drops abruptly toward the mouth. In contrast, the internal zone is shallow (less than $20 \mathrm{~m}$ ) and is bordered by mangroves, muddy or sandy beaches and rocky headlands (Vargas 1996). The gulf dynamic structure is principally controlled by salinity variations (Peterson 1958, Lizano \& Vargas 1994) and strong gradients in physical-chemical parameters during the rainy season. In particular, the internal region of the gulf behaves as an estuary, showing stratification during the rainy season because of reduction in surface salinity (Epifanio et al. 1983). Lizano (1998) showed that the strong saline stratification in the internal region may have an important impact on fisheries in the gulf. The strong seasonal stratification also influences nutrients and dissolved oxygen dynamics (Epifanio et al. 1983, Chaves \& Birkicht 1994) which in turn leads directly to biological differences between the two regions of the gulf(see Vargas 1995). 


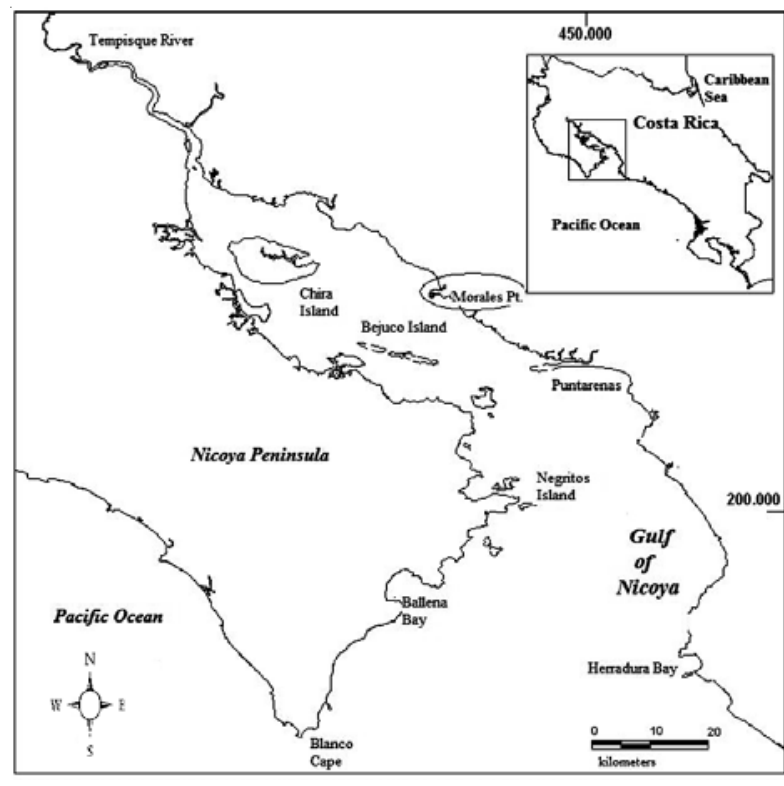

Figure 1

Gulf of Nicoya with study zone (Morales Pt.), Pacific coast, Costa Rica

Golfo de Nicoya con la zona de estudio (Pta. Morales), costa Pacífica, Costa Rica

\section{Sampling program}

Daily samplings in different tide conditions were carried out during two days in one station at two depths from March to May and September to December, 1997 in Estero Punta Morales, internal zone of Gulf of Nicoya (Fig. 1). Surface temperature and oxygen content were measured with an YSI 57 polygraph sensor. Light penetration was measured using a Secchi disc. Twosampling depths were selected: $50 \%$ and $10 \%$ light penetration, which was obtained by multiplying the Secchi depth by the penetration light coefficient $(0.40$ and 1.35 respectively). In both depths salinity (psu) was measured with a Sper Scientific 300011 refractometer and a Niskin bottle (5L) was used to collect samples for chlorophyll analysis and phytoplankton composition. Samples for chlorophyll $a$ analysis were determined by collecting three replicates. Additional samples were taken at each depth for taxonomic work and were fixed with acid Lugol's solution. Oblique zooplankton hauls were carried out with a plankton net of $280 \mu \mathrm{m}$ mesh size with a General Oceanics flowmeter mounted at the net mouth to measure the filtered water volume. Samples were fixed in 5\% formaldehyde.

\section{Sampling analysis}

Samples for total chlorophyll analyses were filtered trough Whatmann GF/C filters and the samples for nannophytoplankton chlorophyll determinations were previously sieved through a $30 \mu \mathrm{m}$ sieve (Malone 1971) and filtered (Whatmann GF/C filter). Chlorophyll analysis was conducted according to Strickland \& Parson (1972). Pigment extraction was done using $90 \%$ acetone, and absorbance was determined by a Shimadzu UV-160 spectrophotometer. Chlorophyll $a$ concentration was calculated according to the equation of SCOR/UNESCO (1966, in Strickland \& Parsons 1972). Net phytoplankton chlorophyll $a$ concentration was calculated as the difference between total chlorophyll $a$ and nannophytoplankton chlorophyll $a$. The water filtered for chlorophyll determinations was collected, refrigerated $\left(0^{\circ} \mathrm{C}\right)$ and inorganic nutrients concentrations (silicate, phosphate, nitrite, nitrate and ammonia) were determined by spectrophotometric analyses according to Strickland \& Parsons (1972). The main taxonomic groups of phytoplankton were determined according to the Utermöhl technique (Utermöhl 1958). Taxonomic identification was done according to Subrahmanyan (1946), Cupp (1977), Humm \& Wicks (1980) and Tomas (1993, 1996). Using a Folsom plankton splitter and depending on the volume of the zooplankton sample, fractions of $1 / 16,1 / 32$ or $1 / 64$ were processed. One fraction was used to determine biomass dry weight and one to determine the composition and abundance of the zooplankton community. Dry weight was measured by collecting the fraction on a pre-weighed filter (Whatmann $\mathrm{GF} / \mathrm{C})$. Filters were dried $\left(24\right.$ hours at $\left.60^{\circ} \mathrm{C}\right)$ and weighed. Total zooplankton biomass is reported as biomass in $\mathrm{mg}$ $\mathrm{m}^{-3}$. Herbivore biomass was determined indirectly according to the seasonal abundance of copepods found by Brugnoli-Olivera et al. (2004) and reported as $\mathrm{mg} \mathrm{m}^{-3}$.

The grazing rate was indirectly estimated by using the pigment budget proposed by Welschmeyer \& Lorenzen (1985), but modified for a mixed environment (1). According to Brugnoli-Olivera \& Morales-Ramírez (1999), the water column of Punta Morales was mixed during the study period. In the present investigation a modification of this budget with some theoretical considerations was carried out: the pheophorbide $a$ was the quantifiable pheopigment, the distribution of phytoplankton pigments and degradation products in the euphotic zone were sampled with a Niskin bottle in different depths at different tides on the same day and, the majority of pheopigment in the Punta Morales zone was provided by mesozooplankton grazing (BrugnoliOlivera 1998), mainly copepod species that were the most abundant group during the study period (Brugnoli-Olivera et al. 2004). With this assumption, the microzooplankton grazing or lateral advection as pheopigment origin was 
not considered. This grazing rate $\left(g=\mathrm{d}^{-1}\right)$ represents the amount of pheopigments removed daily from the permanent phytoplankton biomass. Phytoplankton growth rate $\left(\mu=\mathrm{d}^{-1}\right)$ was determined to evaluate the effect of grazing pressure on the phytoplankton community. Calculated grazing rates $(g)$ from equation (1) were inserted in equation (2) according to Welschmeyer \& Lorenzen (1985). To determine the grazing pressure, it was assumed that the phytoplankton growth rate is balanced through the grazing rate. The grazing pressure was quantified as the daily amount of phytoplankton $(\mu)$ removed from the permanent phytoplankton biomass $(\mathrm{g})$ and expressed as percentage (\%). In equations (1) and
(2), $\mathrm{S}=$ Sum, $1-50 \%=$ light penetration, $\mathrm{T}=$ time (intertide period) (d), Chl- $a=$ chlorophyll $a\left(\mathrm{mg} \mathrm{m}^{-2}\right)$ and phaeo $=$ phaeopigments $\left(\mathrm{mg} \mathrm{m}^{-2}\right)$.

For statistical analysis non parametric Mann Whitney and Kruskall-Wallis tests were used to find differences in temperature, salinity, nutrients concentration, zooplankton or phytoplankton biomass, grazing rate and grazing pressure between depths, tides or times (season or months); Spearman correlation was utilized to find associations between nutrients concentration and salinity at $P<0.05$ level of significance (Zar 1996). Analyses were performed using SYSTAT software package.

$$
\begin{aligned}
& \mathbf{g}\left(\mathrm{d}^{-1}\right)=\left[\frac{(\mathrm{S} \text { phaeo. } 10 \%-50 \% \mathrm{~T} 1)-(\mathrm{S} \text { paheo. } 10 \%-50 \% \mathrm{~T} 0)] \ln \left[(\mathrm{SChl}-a 10 \%-50 \% \mathrm{~T} 1)^{*}(\mathrm{SChl}-a 10 \%-50 \% \mathrm{~T} 0)^{-1}\right]}{\mathrm{T}[(\mathrm{SChl}-a 10 \%-50 \% \mathrm{~T} 1)-(\mathrm{SChl}-a 10 \%-50 \% \mathrm{~T} 0)]}\right. \\
& \boldsymbol{\mu}\left(\mathrm{d}^{-1}\right)=\mathrm{g}+\ln [(\mathrm{SChl}-a 10 \%-50 \% \mathrm{~T} 1)-(\mathrm{SChl}-a 10 \%-50 \% \mathrm{~T} 0)]
\end{aligned}
$$

\section{Results}

\section{Physical-chemical setting}

Surface water temperature showed an average of $29.9 \pm$ $0.9^{\circ} \mathrm{C}$, a variation coefficient of 0.03 ; a maximum value $\left(31.5^{\circ} \mathrm{C}\right)$ in April and a minimum $\left(28^{\circ} \mathrm{C}\right)$ during March and October. There were significant differences between dry-transition and rainy-transition seasons $(P=0.0001$ and $P=0.0015)$. In both depths, salinity showed an average of $26.6 \pm 7.2 \mathrm{psu}$ and a variation coefficient of 0.27 ; the maximum value was $35 \mathrm{psu}$ in December and the minimum was $10 \mathrm{psu}$ in October. There were no significant differences between depths, times or tides $(P>0.05)$. Sub-surface dissolved oxygen showed an average of $6.7 \pm 0.6 \mathrm{mg} \mathrm{L}^{-1}$ with a variation coefficient of 0.08 ; the maximum concentration was observed in November $\left(8.0 \mathrm{mg} \mathrm{L}^{-1}\right)$ and the minimum in December (5.8 $\left.\mathrm{mg} \mathrm{L}^{-1}\right)$. The depth of the Secchi disk had an average of $1.4 \pm 0.5 \mathrm{~m}$ and a variation coefficient of 0.27 ; a maximum value was observed in March $(3 \mathrm{~m})$ and a minimum in October $(0.5 \mathrm{~m})$.

\section{Inorganic nutrients}

During the sampling period, silicate $\left(\mathrm{Si}(\mathrm{OH}) \mathrm{O}^{3-}\right)$ showed a mean concentration of $6.79 \pm 4.40 \mu \mathrm{mol} \mathrm{L} \mathrm{L}^{-1}$ with a variation coefficient of 0.64 ; the maximum value was $19.08 \mu \mathrm{mol} \mathrm{L}{ }^{-1}$ observed during May and non detected values during March and September. Phosphate $\left(\mathrm{P}_{4}{ }^{3-}\right)$ showed a mean concentration of $1.12 \pm 0.81 \mu \mathrm{mol} \mathrm{L}-1$ and the variation coefficient was 0.72 ; values oscillated between a maximum of $3.40 \mu \mathrm{mol} \mathrm{L}^{-1}$ in December and a minimum of $0.17 \mu \mathrm{mol} \mathrm{L}^{-1}$ during may. In the nitrogenate chemical species, nitrate concentration
(NO -) showed a mean value of $1.22 \pm 1.40 \mu \mathrm{mol} \mathrm{L}^{-1}(\mathrm{VC}=$ $1.14)^{3}$ with a maximum of $9.77 \mu \mathrm{mol} \mathrm{L}^{-1}$ in October and non detected values during the dry season and September. Nitrites $\left(\mathrm{NO}_{2}^{-}\right)$concentration showed a mean of $0.43 \pm$ $0.32 \mu \mathrm{mol} \mathrm{L} \mathrm{L}^{-1}$, with a variation coefficient of 0.73 , maximum of $1.64 \mu \mathrm{mol} \mathrm{L}-1$ (September) and non detected concentration during the dry season. Ammonia concentrations $\left(\mathrm{NH}_{4}^{+}\right)$were determined only in March, September, October and December with a maximum of $9.45 \mu \mathrm{mol} \mathrm{L}^{-1}$ during December and a minimum of 1.39 $\mu \mathrm{mol} \mathrm{L} \mathrm{L}^{-1}$ in October (Fig. 2a).

No significant differences were observed in the silicate, phosphate and nitrite concentrations $(P>0.05)$ among months. However, a significant difference was found in nitrate concentration between months in the dry season (March-December, $P=0.007$ ), in the dry and rainy seasons (March-October, $P=0.0002$ ) or transition - dry season (April-December, $P=0.0006$ ) (Fig. 2a). A significant difference in nitrate concentration was found between the dry-transition season $(P=0.0019)$ and the transition-rainy season $(P=0.0015)$ (Fig. 2b). Silicate, phosphate and nitrogenate chemical species, showed a significant correlation $\left(\mathrm{r}_{\mathrm{s}}, P<0.05\right)$ between their concentration and salinity during dry and rainy seasons (Table 1).

\section{Phytoplankton}

A total of 43 phytoplankton taxa were identified with 32 taxa of diatoms, 6 genera of dinoflagellates, 3 of cyanobacteria, one Euglenophyta and one flagellate. 

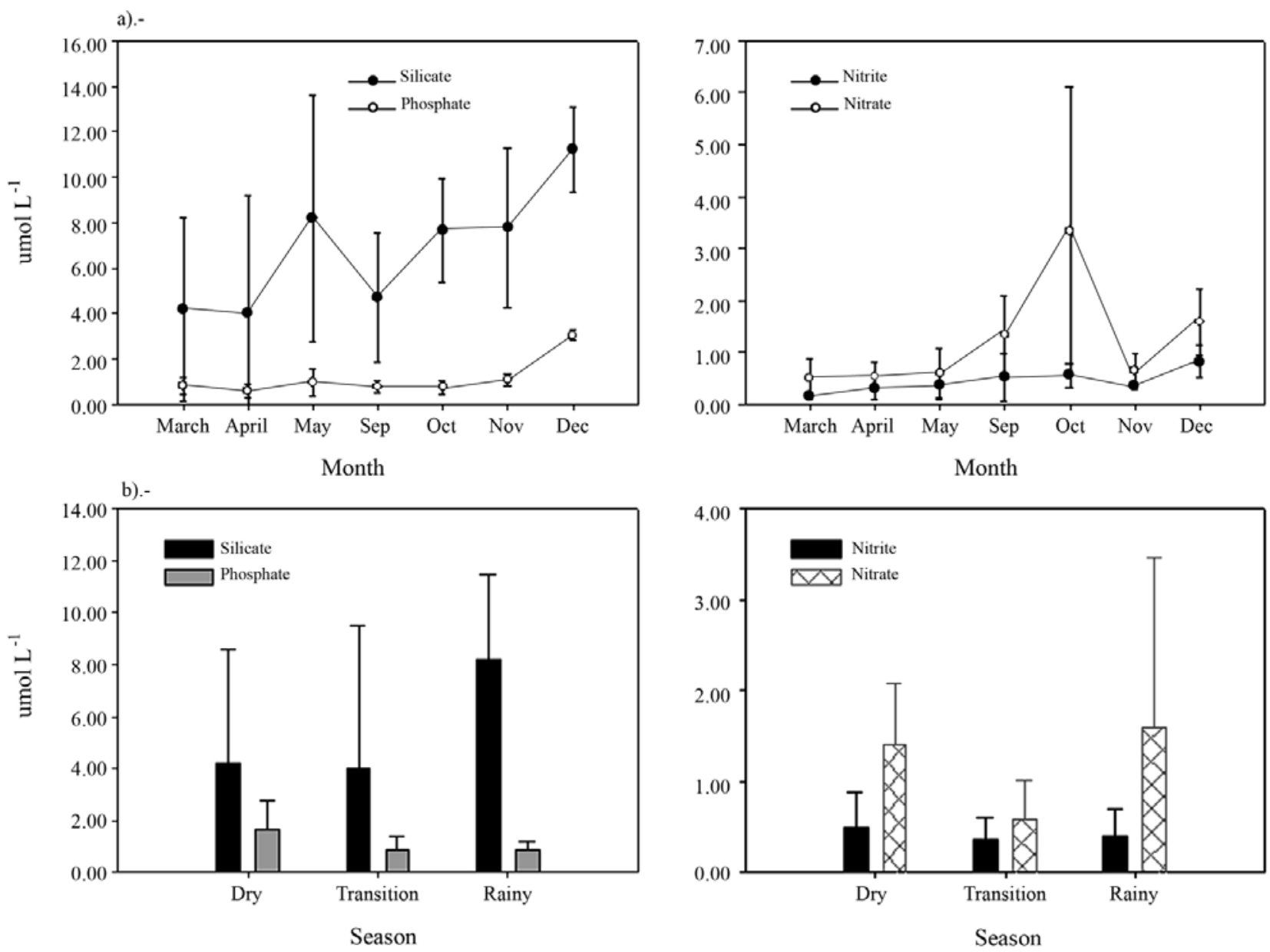

Figure 2

Mean of inorganic nutrient concentration at Punta Morales zone, Gulf of Nicoya, Costa Rica, 1997. a) Monthly variability, b) seasonal variability

Promedio de la concentración de nutrientes inorgánicos en la zona de Punta Morales, Golfo de Nicoya, Costa Rica, 1997.

a) Variación mensual, b) variación estacional

Table 1

Correlations $(P<\mathbf{0 . 0 5})$ between salinity and inorganic nutrient concentrations. Punta Morales zone, Gulf of Nicoya, Costa Rica, 1997. (n=); NS: non-significative

Correlaciones $(P<0,05)$ entre salinidad y concentraciones de nutrientes inorgánicos. Zona de Punta Morales, Golfo de Nicoya, Costa Rica, 1997. ( $n=)$; NS: no significativo

\begin{tabular}{cccccc}
\hline Season & Silicate & Ortophosphate & Nitrate & Nitrite & Ammonia \\
\hline Dry & $0.796_{(26)}$ & $0.591_{(26)}$ & $0.591_{(12)}$ & $0.850_{(20)}$ & $0.800_{(15)}$ \\
Rainy & NS & $0.348_{(32)}$ & $-0.750_{(28)}$ & NS & NS \\
\hline
\end{tabular}


Table 2

Relative abundance of phytoplanktonic taxa in Punta Morales, Gulf of Nicoya, Costa Rica, 1997, during the dry, transition and rainy seasons. 1: Net phytoplankton, 2: Nannophytoplankton

Abundancia relativa de los taxa fitoplantónicos en Punta Morales, Golfo de Nicoya, Costa Rica, 1997 durante las estaciones seca, de transición y lluviosa. 1: Fitoplancton de red, 2: Nanofitoplancton

\begin{tabular}{|c|c|c|c|c|c|c|c|}
\hline \multirow{3}{*}{$\begin{array}{l}\text { Order } \\
\text { Sub Order } \\
\text { Family }\end{array}$} & \multirow{3}{*}{ Genus } & \multicolumn{2}{|c|}{ Dry season } & \multicolumn{2}{|c|}{ Transition season } & \multicolumn{2}{|c|}{ Rainy season } \\
\hline & & 1 & 2 & 1 & 2 & 1 & 2 \\
\hline & & & & & & & \\
\hline \multicolumn{8}{|l|}{ Diatoms } \\
\hline Coscinodiscinae & & 17.5 & 5.4 & 19.8 & 5.4 & 5.6 & 8.0 \\
\hline \multirow[t]{3}{*}{ Thalassiosiraceae } & Lauderia & 0.0 & 0.2 & 0.4 & 0.0 & 0.0 & 0.0 \\
\hline & Skeletonema costatum & 45.7 & 6.6 & 8.2 & 2.0 & 29.2 & 7.1 \\
\hline & Thalassiosira & 0.2 & 0.8 & 0.9 & 1.5 & 0.0 & 0.0 \\
\hline Melosiraceae & Stephanophyxis & 1.0 & 0.1 & 0.9 & 0.3 & 4.4 & 1.4 \\
\hline \multirow[t]{2}{*}{ Leptocylindraceae } & Leptocylindrus & 2.1 & 5.5 & 3.4 & 3.7 & 1.3 & 3.4 \\
\hline & Corethron & 0.0 & 0.2 & 0.0 & 0.0 & 0.0 & 0.1 \\
\hline Coscinodiscaceae & Coscinodiscus & 0.0 & 0.2 & 0.0 & 0.0 & 0.0 & 0.0 \\
\hline Hemidiscaceae & Actynocyclus & 0.1 & 0.2 & 0.3 & 0.0 & 0.0 & 0.0 \\
\hline Asterolampraceae & Asterolmphalus & 0.0 & 0.0 & 0.1 & 0.4 & 0.0 & 0.0 \\
\hline Rhizosoleniineae & Rhizosolenia & 1.2 & 0.5 & 2.5 & 0.2 & 0.1 & 0.0 \\
\hline \multirow[t]{2}{*}{ Rhizosoleniaceae } & Guinardia & 1.2 & 1.3 & 0.7 & 0.3 & 0.9 & 0.3 \\
\hline & Proboscis alata & 0.0 & 0.0 & 0.9 & 0.0 & 0.1 & 0.0 \\
\hline Biddulphiineae & Climocodium & 0.0 & 0.0 & 0.1 & 0.4 & 0.0 & 0.1 \\
\hline \multirow[t]{3}{*}{ Hemiaulaceae } & Eucampia & 0.1 & 0.7 & 0.3 & 0.5 & 0.1 & 0.2 \\
\hline & Hemialus & 0.1 & 0.4 & 0.3 & 0.1 & 0.0 & 0.1 \\
\hline & Heliotheca & 0.1 & 0.1 & 0.1 & 0.1 & 0.0 & 0.0 \\
\hline \multirow[t]{2}{*}{ Chaetocerotaceae } & Bacteriastrum & 0.0 & 0.0 & 0.1 & 0.0 & 0.1 & 0.0 \\
\hline & Chaetoceros & 17.1 & 21.6 & 18.6 & 15.1 & 26.3 & 39.4 \\
\hline \multirow[t]{3}{*}{ Lithodesmiaceae } & Ditylum & 0.8 & 0.5 & 2.6 & 0.2 & 1.7 & 0.7 \\
\hline & Lithodesmiun & 0.0 & 0.7 & 0.0 & 0.0 & 0.0 & 0.0 \\
\hline & Biddulphia & 6.1 & 2.2 & 13.7 & 0.6 & 14.7 & 0.3 \\
\hline Bacilariales & Asterionellopsis & 0.1 & 0.2 & 0.5 & 0.6 & 0.1 & 0.4 \\
\hline Fragilariaceae & Fragilaria & 0.0 & 0.0 & 0.0 & 0.2 & 0.0 & 0.0 \\
\hline \multirow[t]{2}{*}{ Thalassionemataceae } & Thalassionema & 1.6 & 3.3 & 1.5 & 1.5 & 2.7 & 2.6 \\
\hline & Thalassiothrix & 0.0 & 0.5 & 0.1 & 0.4 & 0.0 & 0.2 \\
\hline \multirow[t]{3}{*}{ Naviculaceae } & Navicula & 0.4 & 8.7 & 0.9 & 9.0 & 0.2 & 7.2 \\
\hline & Haslea & 0.4 & 1.4 & 1.2 & 3.0 & 0.5 & 0.0 \\
\hline & Pleurosigma & 1.0 & 0.4 & 2.2 & 0.3 & 0.2 & 0.1 \\
\hline \multirow[t]{3}{*}{ Bacillariaceae } & $\begin{array}{l}\text { Cylindrotheca } \\
\text { closterium }\end{array}$ & 0.2 & 16.5 & 0.6 & 14.8 & 0.0 & 4.1 \\
\hline & Nitzchia & 0.8 & 2.2 & 0.1 & 1.2 & 0.5 & 0.6 \\
\hline & Pseudonitzchia & 0.5 & 0.3 & 0.0 & 1.2 & 0.7 & 1.0 \\
\hline \multirow[t]{6}{*}{ Dinoflagellates } & Ceratium & 1.0 & 0.1 & 13.4 & 0.1 & 2.5 & 0.0 \\
\hline & Dinophysis & 0.1 & 0.0 & 0.2 & 0.0 & 0.7 & 0.0 \\
\hline & Gymnodinium & 0.0 & 0.3 & 0.0 & 0.6 & 0.0 & 0.0 \\
\hline & Peridinium & 0.1 & 0.0 & 0.1 & 0.0 & 0.4 & 0.0 \\
\hline & Protoperidinium & 0.0 & 0.0 & 1.1 & 0.2 & 0.0 & 0.0 \\
\hline & Prorocentrum & 0.0 & 0.4 & 0.5 & 0.2 & 0.8 & 0.1 \\
\hline \multirow[t]{3}{*}{ Cyanophytes } & Anabaena & 0.0 & 1.6 & 1.3 & 1.2 & 5.4 & 0.0 \\
\hline & Johanebaptista & 0.4 & 0.9 & 2.0 & 0.2 & 0.2 & 0.0 \\
\hline & Mycrocystis & 0.0 & 0.1 & 0.0 & 0.0 & 0.6 & 0.0 \\
\hline Euglenophytes & & 0.0 & 0.3 & 0.0 & 0.2 & 0.0 & 0.0 \\
\hline Others Flagellates & & 0.0 & 15.6 & 0.0 & 34.3 & 0.0 & 22.6 \\
\hline Total & & 100.0 & 100.0 & 100.0 & 100.0 & 100.0 & 100.0 \\
\hline
\end{tabular}


Flagellates and diatoms (centric and pennate) represented $90 \%$ of the total phytoplankton abundance. In net phytoplankton, centric diatoms were the most abundant group, while in nannophytoplankton the most abundant groups were flagellates and small diatoms (centric and pinnate). Skeletonema costatum and Cylindrotheca closterium were the species with the highest concentrations. During both dry and rainy seasons $S$. costatum dominated the phytoplankton net fraction, while C. closterium dominated the nannophytoplanktonic fraction during the dry season (Table 2).

Net phytoplankton biomass showed a mean of $3.1 \pm$ $1.7 \mathrm{mg}$ Chl- $a \mathrm{~m}^{-3}$ and a variation coefficient of 0.5 . Maximum values were found in September (7.6 mg Chl$\left.a \mathrm{~m}^{-3}\right)$ and minimum in December (0.1 mg Chl- $\left.a \mathrm{~m}^{-3}\right)$ (Fig. 3a). Nannophytoplankton chlorophyll $a$ had a mean of $2.5 \pm 1.2 \mathrm{mg}$ Chl- $a \mathrm{~m}^{-3}$ and showed a variation
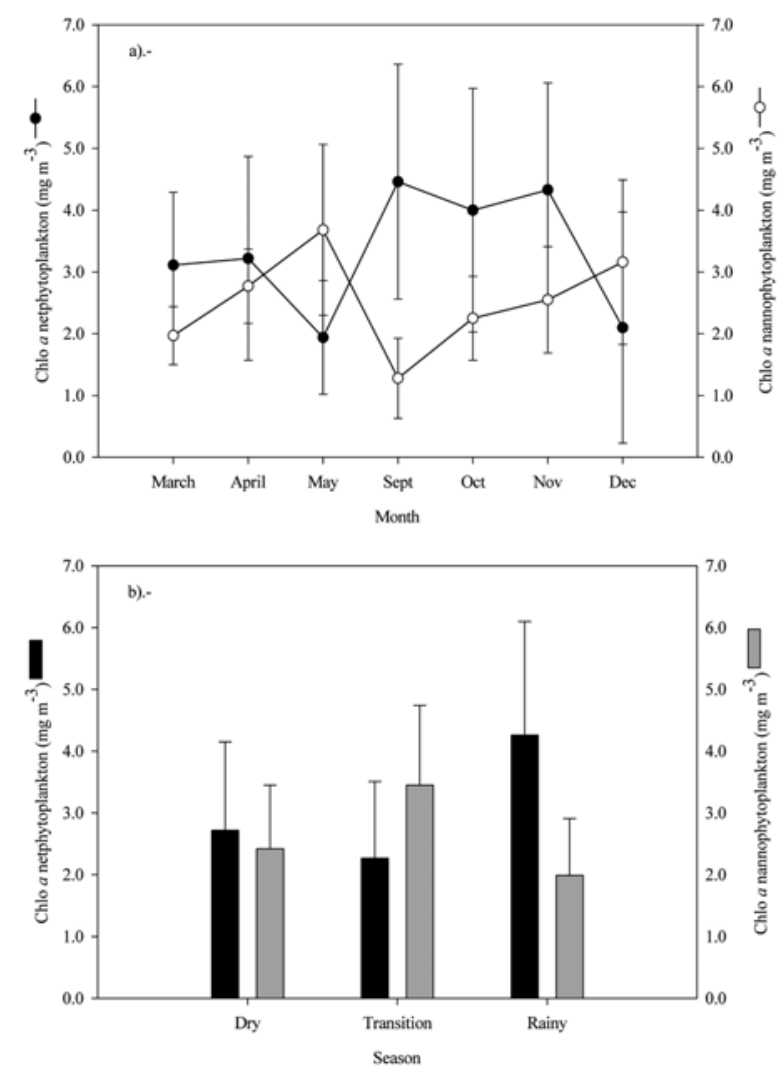

Figure 3

Phytoplankton biomass average at Punta Morales zone, Gulf of Nicoya, Costa Rica, 1997.

a) Monthly variability, b) seasonal variability

Promedio de biomasa de fitoplancton en la zona de Punta Morales, Golfo de Nicoya, Costa Rica 1997.

a) Variación mensual, b) variación estacional coefficient of 0.4. During May we observed the maximum concentration (5.9 mg Chl- $a \mathrm{~m}^{-3}$ ) and in September the minimum (0.5 mg Chl- $a \mathrm{~m}^{-3}$ ) (Fig. 3a). Non significant differences were observed in the biomass of the two fractions between the sampling depths. However, there was a significant difference for the two fractions between the transition and rainy seasons $(P=0.0000, P=0.0001)$, for net phytoplankton between the dry and rainy seasons $(P=0.003)$, and for nannophytoplanktonic biomass between the dry and transition seasons $(P=0.009)$ (Fig. 3b).

\section{Zooplankton}

The mesozooplankton community was characterized by the presence of holo and meroplanktonic groups, such as copepods, chaetognaths, crustacean larvae, ostracods, cladocerans, fish larvae, molluscs, appendicularians, echinoderms and brachiopods larvae (Brugnoli-Olivera et al. 2004). In this community, copepods were the most abundant group with a maximum of 5877 ind. $\mathrm{m}^{-3}$ during May, a minimum of 438 ind. $\mathrm{m}^{-3}$ in March and a mean of $2602 \pm 2021$ ind. $\mathrm{m}^{-3}$. A total of 12 species were identified, with Acartia lilljeborgii, Pseudodiaptomus sp. and Paracalanus parvus being the dominant herbivores (Table 3).

Total zooplankton biomass showed a mean of $66.4 \pm$ $45.5 \mathrm{mg} \mathrm{m}^{-3}$ and a variation coefficient of 0.69 . A maximum value (215.9 $\left.\mathrm{mg} \mathrm{m}^{-3}\right)$ was obtained during April and a minimum (20.7 $\mathrm{mg} \mathrm{m}^{-3}$ ) in September (Fig. 4a). During the study, we observed a significant difference between the dry and the transitional seasons $(P=0.014)$

\section{Table 3}

\section{Mean abundance (ind $\mathrm{m}^{-3}$ ) of copepod species in Punta Morales, Gulf of Nicoya, Costa Rica, 1997}

Abundancia promedio (ind $\mathrm{m}^{-3}$ ) de las especies de copépodos en Punta Morales, Golfo de Nicoya, Costa Rica, 1997

\begin{tabular}{lc}
\hline \multicolumn{1}{c}{ Species } & Mean \\
\hline Acartia lilljeborgii & 2154 \\
Pseudodiaptomus sp. & 319 \\
Paracalanus parvus & 150 \\
Canthocalanus pauper & 52 \\
Euterpina acutifrons & 23 \\
Hemyciclops thalassius & 11 \\
Corycaeus sp. & 4 \\
Centropages furcatus & 1 \\
Pseudodiaptomus wrighti & 1 \\
Subeucalanus monachus & 1 \\
Paracalanus panamensis & 1 \\
Paracalanus crassirostris & 1 \\
\hline
\end{tabular}



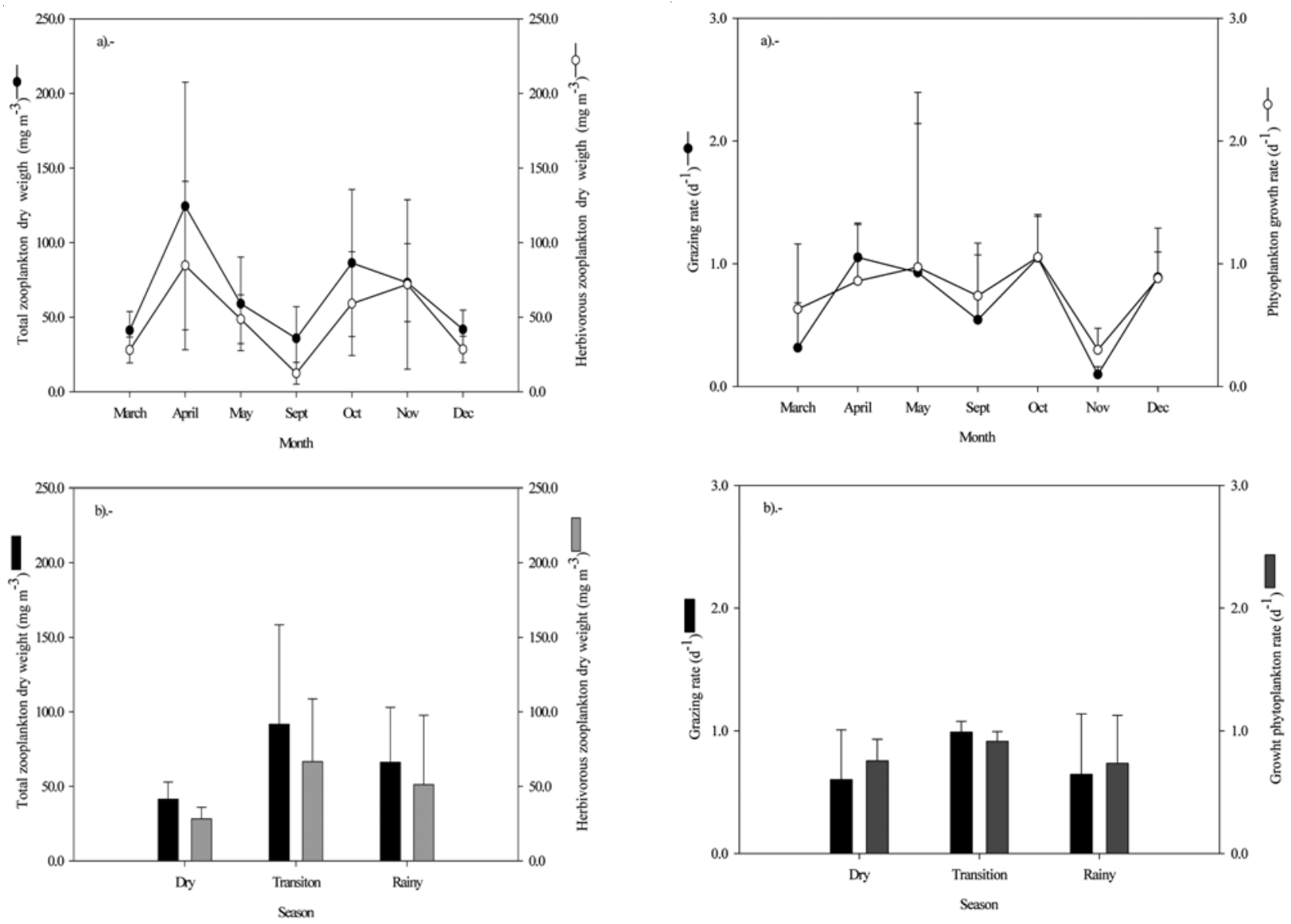

Figure 4

Figure 5

Total and herbivorous zooplankton biomass at Punta Morales zone, Gulf of Nicoya, Costa Rica, 1997. a) Monthly average, b) seasonal average

Biomasa total y del zooplancton herbívoro en la zona de Punta Morales, Golfo de Nicoya, Costa Rica, 1997.

a) Promedio mensual, b) promedio estacional

(Fig. 4b). Herbivore biomass showed a mean of $48.8 \pm$ $37.8 \mathrm{mg} \mathrm{m}^{-3}$, and a variation coefficient of 0.77 . The maximum value was obtained in April (146.8 $\mathrm{mg} \mathrm{m}^{-3}$ ) while in September the biomass was $7.1 \mathrm{mg} \mathrm{m}^{-3}$ (Fig. 4a).

\section{Indirect grazing pressure}

Grazing rate showed a mean of $0.67 \pm 0.83 \mathrm{~d}^{-1}$ and a variation coefficient over 1 . During May the highest and lowest grazing rate were obtained $\left(3.82 \mathrm{~d}^{-1}\right.$ and $0.004 \mathrm{~d}^{-1}$, respectively) (Fig. 5a). Phytoplankton growth rate showed a mean of $0.77 \pm 0.66 \mathrm{~d}^{-1}$, with a maximum of $3.16 \mathrm{~d}^{-1}$ and a minimum of $0.04 \mathrm{~d}^{-1}$, both in May (Fig. 5a).

Primary biomass removal by grazing pressure was $57.65 \pm 35.1 \%$, with a variation coefficient of 0.57 ; the minimum value was in May $(9.79 \%)$ and there was over $100 \%$ consumption during September and October. There was a marginal difference in the grazing rate and the grazing pressure between seasons $(P=0.05)$.

\section{Discussion}

\section{Environmental and abiotic factors}

Vargas (1996) classified December to April as a dry season and May to November as a rainy season. However, according to the average monthly precipitation data of 1997 at the Punta Arenas meteorological station, this study classified December and March as dry season, 
April-May as transition season and September to November as rainy season.

During the 1997-1998 El Niño event, McPhaden (1999) found great physical and biological changes in the Equatorial Pacific. According to Brugnoli-Olivera \& Morales-Ramírez (1999) and Morales-Ramírez \& Brugnoli-Olivera (2001) an El Niño event was detected in the Punta Morales zone during the sampling period reflected by a change in the physico-chemical water characteristics and by a possible dynamic plankton modification (phyto and zooplankton). Furthermore, correlations between salinity and nutrient concentrations during the dry season suggest an input of oceanic water into the sampling zone (Brugnoli-Olivera \& MoralesRamírez 1999). Brenes et al. (1996) found and oceanic influence in the Gulf of Nicoya and Víquez (1983) suggested that this occur principally during dry seasons. Moreover, during the rainy season an inverse correlation between nitrate and salinity (Table 1) occurred, suggesting nutrient inputs by the rivers situated near Punta Morales zone. In this season nitrate concentration showed its maximum and minimum values with a high variation coefficient suggesting a pulse of nutrients input to the Punta Morales zone.

\section{Phytoplankton community behavior}

During this study, flagellates and diatoms (centric and pennated) represented $90 \%$ of the total phytoplankton abundance. The most abundant group of the phytoplankton sampled by Niskin bottle, were centric diatoms, while in the nannophytoplankton the flagellates and diatoms were the most abundant. Changes in the phytoplankton structure through nutrient competition result in an ecological succession through time, while changes originated through advection or water mass transport, produce a phytoplankton sequence (Margalef 1997). Phytoplankton communities dominated by centric diatoms are characteristic of coastal regions ( $\mathrm{D}^{\prime} \mathrm{Croz}$ et al. 1991) and dominate rich nutrient environments (Ishizaka et al. 1986) although small diatoms and flagellates are very common in other latitudes (Booth \& Smith 1997). Diatoms, which depend on water movement to remain suspended in the water column and access to microzones rich in nutrients (Margalef 1997), show a major nutrient absorption in turbulent systems (Kiørbe 1993) and dominate the environment with high nutrients concentrations, light availability and turbulence (Stolte 1996). In this study, during rainy and dry seasons the phytoplankton communities exhibited higher biomass in the net phytoplankton fraction (Fig. 3b), where higher nutrient values were found (Fig. 2b). These results suggest the existence of ecological succession of phytoplankton in the Punta Morales zones (Brugnoli-Olivera \& MoralesRamírez 2001). The absence of significant differences between sampling days and between days in the same season, suggests the existence of a typical net phytoplankton community. However, the nannophytoplanktonic cell number showed significant differences between seasons (Brugnoli-Olivera \& Morales- Ramírez 2001).

Moreover, nannophytoplanktonic biomass showed a reduced variation compared with net phytoplankton biomass and these results are in agreement to Hopcroft \& Roff (1990). These authors suggested a major stability in this nannophytoplanktonic fraction than in the net phytoplankton. It is possible that the water surface temperature in the Punta Morales zone determines this phytoplankton biomass behavior and may be associated with the El Niño event during the sampling time.

The phytoplankton growth rates found in this study (mean $\left.0.77 \mathrm{~d}^{-1}\right)$ were between expected ranges $(0.093$ $\left.1.03 \mathrm{~d}^{-1}, 0.46-0.92 \mathrm{~d}^{-1}\right)$ for phytoplankton in coastal areas (Ryther 1969, Harvey et al. 1953 fide Ketchum 1954), and agreed with the phytoplankton growth rate $(0.53$ $0.815 \mathrm{~d}^{-1}$ ) reported by Welschmeyer \& Lorenzen (1985) for tropical ocean zones. Furthermore, the maximum phytoplankton growth observed during this study (3.16 $\mathrm{d}^{-1}$ ), was similar to those measured in artificial phytoplankton cultures at $26^{\circ} \mathrm{C}$ and continuous light regimes (Eppley et al. 1972 fide Cullen et al. 1992). However, these growth rates were calculated indirectly on the basis of a theoretical model adding the grazing rates and the chlorophyll $a$ increasing to a time range corresponding to a inter-tidal period. This could be an important aspect of variability for phytoplankton growth rates, especially in Punta Morales where the tide amplitude can vary between 0 and $3 \mathrm{~m}$.

\section{Zooplankton dynamics}

The zooplankton community composition corresponds to Raymont's (1980) description of estuarine zooplankton communities. These results fit with the estuarine status suggested for the Gulf of Nicoya by Peterson (1958) and Voohris et al. (1983). In the holoplankton, copepods were the more abundant group and the number of copepods species ( $=12$ ) agreed to that reported by Morales-Ramírez \& Vargas (1995). Others studies showed similar trends of lower diversity in bays and estuaries in the copepod community (Uye 1994), with few species dominant in abundance terms (Hopcroft et al. 1998). During the study period, Acartia lilljeborgii, Pseudodiaptomus sp. and $P$. parvus were the most abundant species (Table 3 ) and these species are typical of estuarine regions (Bjönberg 1981). Acartia is a very common genus in neritic coastal areas 
(Palomares-García \& Gómez-Gutierrez 1996) and generally dominates such environments (Kimmerer \& MacKinnon 1987). It is probable that Acartia spp. dominate these environments through their ability to maintain high clearance rates (Paffenhöfer \& Stearns 1988), increasing reproductive rates (Turner, 1984), by euryphagous feeding habitats (Palomares-García \& Gómez-Gutierrez 1996) or their adaptation to turbulent environments (Kiørbe \& Saiz 1995).

In the present study, three of the most abundant species of copepods (A. liljeborgii, Pseudodiaptomus spp. and $P$. parvus) are considered herbivorous and responsible for the mesozooplankon grazing pressure. Acartia spp. feed on phytoplankton (Paffennöfer \& Stearns 1988) and Paracalanus is also mainly herbivorous (Turner 1984). On the other hand, although there is no information on the feeding behavior of Pseudodiaptomus spp., they are commonly associated with Acartia spp. in coastal areas (Walter 1989) with high phytoplankton concentrations (Malone 1980). Other important herbivorous organisms in the pelagic environment are appendicularians and microzooplankton (Tönnesson et al. 2005). In this research, appendicularians showed relative abundances less than 1\% (Brugnoli-Olivera et al. 2004) and we did not consider the effect of microzooplankton as potential grazer on the nannophytoplaktonic fraction.

Mean values of dry weight biomass found for herbivorous copepods coincided with those found in other neritic tropical areas $\left(0.6-50 \mathrm{mg} \mathrm{m}^{-3}\right)$ (Hopcroft et al. 1998), but they were different from the mean values for oceanic tropical areas $\left(10 \mathrm{mg} \mathrm{m}^{-3}\right)$ (Chisholm \& Roff 1990). Seasonal differences in herbivore biomass (Fig. 4b) suggest a change in copepod biomass and coincide with the patterns found by von Wangelin \& Wolff (1996) in the Gulf of Nicoya. In our study, maximum averages were found in transitional season and minimum in dry season (Fig. 4b), different from those found by von Wangelin \& Wolff(1996). It is possible that the maximum zooplankton biomass found in transitional season was a direct effect of the grazing on the nanophytoplakton fraction and indirect effect of El Niño (Morales-Ramírez \& Brugnoli-Olivera 2001). Predation on herbivores influences both their biomass and abundance (Marazzo \& Nogueira 1996, Wiafe \& Leslie 1996). During the dry season chaetognath populations increased in the Gulf of Nicoya (Hossfeld 1996), and a significant fraction of the herbivorous copepods can be preyed upon (Kimmerer 1991), decreasing their biomass and size structure (Sterner et al. 1992). Von Wangelin \& Wolff(1996) found a discontinuous biomass in the upper part of Gulf of Nicoya during December, which was concentrated in the smallest size class. In the present study, during the dry season herbivorous copepods showed their lowest biomass (Fig. 4b), which could be associated with predation by chaetognaths or gelatinous zooplankton. Predation could be an important aspect in the regulation of herbivorous copepods in the Punta Morales zone.

\section{Phyto-zooplankton coupling}

In Punta Morales, the indirect theoretical estimation of the herbivory by the three most abundant copepod species (A. liljeborgii, Pseudodiaptomus spp. and P. parvus) reached an average of $57.6 \%$, and a variation coefficient of 0.57 of phytoplankton biomass. This value is higher than that reported for the equatorial Pacific (47\%) (Zhang et al. 1995), but agrees with the variations found in the grazing pressure (between 35 and 68\%) (Sautour et al. 1996) with high variability (5-100\%) (Perissinotto 1992). On the other hand, some studies (Paffenhöfer et al. 1995) have shown feeding rates similar to our calculated grazing pressure $(35 \%-65 \%$, V.C. $=57 \%)$. Feeding rate can be considered an estimate of grazing pressure because both are influenced by size, concentration, food quality (De Mott 1988, Kleppel 1993) and clearance rate, which varies with feeding characteristics of the herbivorous species (Paffenhöfer 1988).

The variation in the grazing pressure may be originated from changes in turbulence intensity (Costello et al. 1990), mixture effects of tides and/or wind (LaraLara \& Matus-Herrera 1997) or the non-synchronous and intermittent feeding of Acartia spp., with respect to the spatio- temporal availability of food (Sautour et al. 1996). Brugnoli-Olivera \& Morales-Ramírez (1999) found temporal changes in turbulence of the water column in the Punta Morales region, dominance of $A$. lilljeborgii in the mesozooplankton (Brugnoli-Olivera et al. 2004) and this study showed seasonal changes in the availability of phytoplankton food (Fig. 3b). The herbivore pressure and rate of herbivory showed marginal differences among seasons (Fig. 5b), suggesting a seasonal behavior in the herbivore community, as it was observed in biomass (Fig. 4b). This seasonal behavior in the herbivory rate should be explained by a direct effect of food availability, food quality, or both, and indirect effects of the El Niño that modifies the environmental conditions. These results suggest a coupling between herbivores and phytoplankton in the internal zone of Gulf of Nicoya during this study.

During both the dry and rainy seasons, phytoplankton growth rates were higher than grazing rates (Fig. 5b), suggesting that herbivorous copepods were not playing a main role in controlling phytoplanktic biomass. When $\mu$ (phytoplankton growth rate) is higher than $g$ (grazing rate), phytoplankton growth rate can be determined mainly through the environmental properties which 
control cell division rate (e.g. light availability and nutrient concentration, Frost 1980). During the rainy and dry seasons phytoplankton communities exhibited higher biomass in the net phytoplankton fraction (Fig. 3b), where higher nutrients values were found (Fig. 2b). On the other hand, Acartia spp., e.g. A. tonsa, can discriminate between cells having different growth rates and chemical composition (Cowles et al. 1988). Probably, during most of the year, herbivorous copepods selectively consumed cells with higher growth. If there is a major selective grazing pressure, phytoplankton shows a major growth but its composition will depend on herbivory and some species can dominate (Frost 1980), as observed in this study with Skeletonema costatum during the dry and rainy seasons, when the net phytoplankton fraction dominated. $S$. costatum shows high growth rates and competes better in environments with high nitrate concentrations (Eppley et al. 1969). Probably, during these periods $S$. costatum had a high growth rate with large cells (Turner \& Roff 1993), and were consumed by herbivorous copepods (Martin 1970 fide Smayda 1980). This suggests that the three species of copepods may present selective grazing, which regulates the species composition of phytoplankton, but not its biomass. Selective grazing agrees with the optimal grazing theory, which predicts a major discrimination on the basis of food quality when the latter is abundant (De Mott 1988).

On the other hand, during the transition season the grazing rate overcomes the phytoplankton growth rate (Fig. 5b). In this case, if the grazing pressure is higher than growth rate, $\mu$ is not strongly related to the environmental properties that affect cell division (Frost 1980). During this season, maximum phytoplankton biomass was found in the nannophytoplankton fraction (Fig. 3b) with a possible limitation of nutrients for the net phytoplankton fraction (Brugnoli-Olivera 1998). Acartia species are opportunistic and prefer large particles (Turner 1984) because of their mouth appendices, which prevent feeding effectively on small cells (Irigoien et al. 1993). Furthermore, it appears that Acartia lilljeborgii is a non selective consumer of net phytoplankton, during the transitional season when food is found in low concentrations, which was also observed by De Mott (1988). Non selective grazing produces slower phytoplankton growth than no grazing, but phytoplankton composition depends more on relative growth rates than on grazing pressure (Frost 1987). We observed a higher number of taxa of net phytoplankton during the transitional period in comparison with the other seasons (Brugnoli-Olivera \& Morales-Ramírez 2001), which suggests that during the transitional season herbivorous copepods controlled net phytoplankton biomass, but its structure was regulated through differential phytoplankton growth rates. For this period, phytoplanktonic population parameters change rapidly and the communities are dominated by small species groups (Víquez 1983).

During the study, an El Niño event was detected through the change of the environmental and biological conditions (Brugnoli-Olivera \& Morales-Ramírez 1999, Morales-Ramírez \& Brugnoli- Olivera 2001). This event could explain the no normal phyto-zooplankton coupling pattern observed in the Gulf of Nicoya.

Although the Gulf of Nicoya is situated in a tropical zone, this study showed a seasonal behavior in the different components (biotic and abiotic) analysed. Furthermore, the results suggested that changes in nutrient concentrations, availability of phytoplankton, rising temperatures through the El Niño event during 19971998, predation and grazing pressure produced changes in the structure of natural plankton (phyto and zooplankton) populations in the Punta Morales zone, Gulf of Nicoya. Future studies including in situ sampling and experimental analysis, are necessary to determine the importance and the regulation factors for the plankton trophic dynamics in this system under normal and nonormal conditions (El Niño event).

\section{Acknowledgments}

This work was part of the Magister thesis of the first author in the Universidad de Costa Rica. We thank the Spanish Mutis programme (AECI) for supporting this study. This work was supported through a grant to A. Morales-Ramírez (808-97-272) from the Vicerrectoría de Investigación of the Universidad de Costa Rica. We thank Paul Hanson for the English corrections of the manuscript and the critical improvement by three reviewers.

\section{Literature cited}

Ban S, C Burns, J Castel, Y Chaudron, E Christou, R Escribano, SF Umani, S Gasparini, FG Ruiz, M Hoffmeyer, A Ianora, HK Kang, M Laabir, A Lacoste, A Miralto, $X$ Ning, $S$ Poulet, $V$ Rodriguez, $J$ Runge, $J$ Shi, M Starr, S Uye \& Y Wang. 1997. The paradox of diatom-copepod interactions. Marine Ecology Progress Series 157: 287-293.

Begon M, JL Harper \& CR Towsend. 1988. Ecology individuals, population and communities, $876 \mathrm{pp}$. Blackwell, Oxford.

Bjönberg TKS. 1981. Copepoda. En: Boltovskoy D. (ed). Atlas del Zooplancton del Atlántico Sudoccidental y métodos de trabajo con el zooplancton marino. pp: 587-679. Mar del Plata: INEDEP 
Booth B \& W Smith. 1997. Autothrophic flagellates and diatoms in the Northeast Water Polynya, Greenland: Sumer 1993. Journal of Marine Systems 10: 241-246.

Brenes C, S León \& G Arroyo. 1996. Influence on some physical and chemical oceanographic characteristics of Gulf of Nicoya, Costa Rica. Tópicos en Meteorología y Oceanografía 3: 65-72.

Brugnoli-Olivera E. 1998. Factores abióticos y bióticos que regulan la estructura y dinámica de la comunidad fitoplánctica en la zona de Punta Morales, Golfo de Nicoya. Tesis de Maestría, Universidad de Costa Rica, San Pedro, Costa Rica, 133 pp.

Brugnoli-Olivera E \& A Morales-Ramírez. 2001. La comunidad fitoplánctica de Punta Morales, Golfo de Nicoya, Costa Rica. Revista de Biología Tropical 49: 1117.

Brugnoli-Olivera E \& A Morales-Ramírez. 1999. Parámetros físico-químicos de la columna de agua en la zona de Punta Morales, Golfo de Nicoya, durante un evento «El Niño». Tópicos en Meteorología y Oceanografía 6: 52-57.

Brugnoli-Olivera E, E Férguson-Díaz, M Delfino-Machin, A Morales-Ramírez \& A Dominici. 2004. The composition of zooplankton community with emphasis on copepods in the Punta Morales zone, Golfo de Nicoya, Costa Rica. Revista de Biología Tropical 52: 897-902.

Calbet A. 2001. Mesozooplankton grazing effect on primary production: a global comparative analysis in marine ecosystems. Limnology and Oceanography 46: 1824-1830.

Carpenter S, M Elser \& M Elser. 1986. Chlorophyll production, degradation and sedimentation: Implications for paleolimnology. Limnology and Oceanography 31: 12-124.

Chaves J \& M Birkicht. 1994. Nutrient pofile. Leng 1-4: Macroscale evaluation. In: Wolf M \& JA Vargas (eds), R.V. Victor Hensen Costa Rica Expedition 1993/1994, pp. 1017. Cruise report. ZMT Bremen Contribution.

Chisholm L \& J Roff. 1990. Abundances, growth rates, and production of tropical neritic copepods off Kingston, Jamaica. Marine Biology 106: 79-89.

Córdoba-Muñóz R. 1993. Productividad primaria en la columna de agua. Golfo de Nicoya, Costa Rica. Tesis de Maestría, Universidad de Costa Rica, San Pedro, Costa Rica, 73 pp.

Costello J, J Strickler, C Marrasé, G Trager, R Zeller \& A Freise. 1990. Grazing in a turbulent environment: behavior response of a calanoid copepod, Centropages hamatus. Proceedings of the Natural Academic of Sciences USA 87: 1648-1652.

Cowles T, R Olson \& S Chishol. 1988. Food selection by copepods: discrimination on the basis of food quality. Marine Biology 100: 41-49.
Cullen J, M Lewis, D Curtis \& R Barber. 1992. Photosynthetic characteristics and estimated growth rates indicate grazing is the proximate control of primary production in the Equatorial Pacific. Journal of Geophysical Research 97(C1): 639-654.

Cupp E. 1977. Marine plankton of the west coast of North America. 237 pp. Doeltz Science Pub., Koenigstein.

Dam H, CA Miller \& SH Jonasdottir. 1993. The trophic role of mesozooplankton at $47^{\circ} \mathrm{N}, 20^{\circ} \mathrm{W}$ during the North Atlantic Bloom Experiment. Deep Sea Research II 40(1/ 2): $197-212$.

D’Croz L, J Del Rosario \& J Gómez. 1991. Upwelling and phytoplankton in the Bay of Panama. Revista de Biología Tropical 39: 233-241.

De Mott WR. 1988. Discrimination between algae and artificial particles by freshwater and marine copepods. Limnology and Oceanography 33: 397-408.

Epifanio CE, D Maurer \& AI Dittel. 1983. Seasonal changes in nutrients and dissolved oxygen in the Gulf of Nicoya, a tropical estuary on the Pacific coast of Central America. Hydrobiologia 101: 231-238.

Eppley R, J Rogers \& J McCarthy. 1969. Half-saturation constants for uptake of nitrate and ammonium by marine phytoplankton. Limnology and Oceanography 14: 912-920.

Frost BW. 1980. Grazing. In: Morris I (ed), The physiological ecology of phytoplankton, pp: 405-492. University of California Press, Berkeley.

Frost BW. 1987. Grazing control of phytoplankton stock in the open subarctic Pacific Ocean: a model assessing the role of mesozooplankton, particulary the large calanoid copepods Neocalanus spp. Marine Ecology Progress Series 39: 49-68.

Gocke K, J Cortés \& MM Murillo. 2001. The annual cycle of primary productivity in a tropical estuary: the inner regions of the Golfo de Nicoya, Costa Rica. Revista de Biología Tropical 49: 289-306.

Hargraves PE \& R Víquez. 1985. Spatial and temporal distribution of phytoplankton in the Gulf of Nicoya, Costa Rica. Bulletin Marine of Science 37: 557-585.

Harris RP, PH Wiebe, J Lenz, HR Sokjoldal \& M Huntley. 2000. Zooplankton Methodology Manual, 684 pp. Academic Press, San Diego.

Hopcroft R \& JC Roff. 1990. Phytoplankton size fractions in a tropical neritic ecosystem near Kingston-Jamaica. Journal of Marine Research 12: 1069-1088.

Hopcroft R, JC Roff \& D Lombard. 1998. Production of tropical copepods in Kingston Harbour, Jamaica: the importance of small species. Marine Biology 130: 593-604.

Hossfeld B. 1996. Distribution and biomass of species of chaetognats in Golfo de Nicoya and Golfo Dulce, Costa Rica. Revista de Biología Tropical 44 (3): 157-172. 
Humm H \& S Wicks. 1980. Introduction and guide to marine blue green algae, 194 pp. Wiley \& Sons, New York.

Ianora A, A Miralto, SA Poulet, Y Carotenuto, I Buttino, G Romano, R Casotti, G Pohnert, T Wichard, L ColucciD’Amato, G Terrazzano \& V Smetacek. 2004. Aldehyde suppression of copepod recruitment in blooms of a ubiquitous planktonic diatom. Nature 429: 403-407.

Ikeda Y, Y Kanno, K Ozaki \& A Shinada. 2001. Metabolic rates of epipelagic marine copepods as a function of body mass and temperature. Marine Biology 139: 587-596.

Irigoien X, J Castel \& B Satour. 1993. In situ grazing activity of planktonic copepods in the Gironde estuary. Cahiers de Biologie Marine 34: 225-237

Irigoien X, RP Harris, HM Verheye, P Joly, J Runge, M Starr, D Pond, R Campbell, R Shreeve, $P$ Ward, AN Smith, HG Dam, W Peterson, V Tirell, M Koski, T Smith, D Harbour \& R Davidson. 2002. Copepod hatching success in marine ecosystems with high diatom concentrations. Nature 419: 387-389.

Ishizaka J, M Takahashi \& S Ichimura. 1986. Changes in the growth rate of phytoplankton in local around the Izu Peninsula, Japan. Journal of Plankton Research 8: 169-181.

Jones RH \& KJ Flynn. 2005. Nutritional status and diet composition affect the value of diatoms as copepod prey. Science 307: 1457-1459.

Ketchum B. 1954. Relation between circulation and planktonic populations in estuaries. Ecology 35: 191-200.

Kimmerer W \& AD MacKinnon. 1987. Growth, mortality, and secondary production of copepod Acartia tranteri in Westernport Bay, Australia. Limnology and Oceanography 32: $14-28$.

Kimmerer W. 1991. Predatory influences on copepod distributions in coastal waters. In: Uye SI, S Nishida \& JS Ho (eds), pp. 161-174. Proceedings of the Fourth International Conference on Copepoda. Bulletin of the Plankton Society of Japan Special Volume, Hiroshima.

Kiørbe T. 1993. Turbulence, phytoplankton cell size, and the structure of pelagic food webs. Advances in Marine Biology 29: 1-73.

Kiørbe T \& E Saiz. 1995. Planktivorous feeding in calm and turbulent environments, with emphasis on copepods. Marine Ecology Progress Series 122: 133-145.

Kleppel GS , DV Holliday \& RE Pieper. 1991. Trophic interactions between copepods and microplankton: a question about the role of diatoms. Limnology and Oceanography 36: 172-178.

Kleppel GS. 1993. On the diets of calanoid copepods. Marine Ecology Progress Series 99: 183-195

Lalli CM \& TR Parsons. 1997. Biological Oceanography. An Introduction, 314 pp. Pergamon Press, Oxford.
Lara-Lara J \& M Matus-Herrera. 1997. Daily zooplankton grazing rates off the coast of Baja California. Ciencias Marinas 23: 71-81.

Lenz J. 1992. Microbial loop, microbial food web and classical food chain: their significance in pelagic marine ecosystem. Archives für Hidrobiologie 37: 265-278.

Lenz J, A Morales \& J Gunkel. 1993. Mesozooplankton standing stock during the North Atlantic spring bloom study and its potencial grazing pressure on phytoplankton: a comparison between low, medium and high latitudes. Deep Sea Research II 40(1/2): 559-572.

Lizano OG. 1998. Dinámica de las aguas en la parte interna del Golfo de Nicoya ante altas descargas del río Tempisque. Revista de Biología Tropical 46: 11-20.

Lizano $O$ \& JA Vargas. 1994. Distribución espacio temporal de la salinidad y la temperatura en la parte interna del Golfo de Nicoya. Tecnología en Marcha 12: 3-16.

Malone TC. 1971. The relative importance of nannoplankton and netplankton as primary producers in tropical oceanic and neritic phytoplankton communities. Limnology and Oceanography 16: 633-639.

Malone TC. 1980. Algal size. In: Morris I (ed), The physiological ecology of phytoplankton, pp: 433-464. University of California Press, Berkeley.

Marazzo A \& CS Nogueira. 1996. Composition, spatial and temporal variations of Chaetognata in Guanabara Bay, Brazil. Journal of Plankton Research 18: 2367-2377.

Margalef R. 1997. Turbulence and marine life. Scientia Marina 69: 109-123.

McPhaden MJ. 1999. Genesis and evolution of the 1997-1998 El Niño. Science 283: 950-954.

Morales CE, A Bedo, RP Harris \& PRG Tranter. 1991. Grazing of copepods assemblages in the north-east Atlantic: the importance of the small size fraction. Journal of Plankton Research 13: 455-472.

Morales-Ramírez A \& JA Vargas. 1995. Especies comunes de copépodos (Crustacea: Copepoda) pelágicos del Golfo de Nicoya, Costa Rica. Revista de Biología Tropical 43: 207-218.

Morales-Ramírez A. 1996. Checklist of copepods from Gulf of Nicoya, Coronado Bay and Golfo Dulce, pacific coast of Costa Rica, with comments on their distribution. Revista de Biología Tropical 44: 103-113.

Morales-RamírezA \& E Brugnoli-Olivera. 2001. El Niño 19971998 impact on the plankton dynamics in the Gulf of Nicoya, pacific coast of Costa Rica. Revista de Biología Tropical 49: 103-114.

Morales-RamírezA. 2001. Biodiversidad marina de Costa Rica, los microcrustáceos: Subclase Copepoda (Crustacea: Maxillopoda). Revista de Biología Tropical 49: 115-133. 
Paffenhöfer G. 1988. Feeding rates and behavior of zooplankton. Bulletin of Marine Sciences 43: 430-445.

Paffenhöfer G \& D Stearns. 1988. Why is Acartia tonsa (Copepoda: Calanoida) restricted to nearshore environments?. Marine Ecology Progress Series 42: 3338.

Paffenhöfer G, M Bundy, K Lewis \& M Metz. 1995. Rates of ingestion and their variability between individual calanoid copepods: direct observations. Journal of Plankton Research 17: 1573-1585.

Paffenhöfer GA. 2002. An assessment of the effects of diatoms on planktonic copepods. Marine Ecology Progress Series 305: $305-310$.

Palomares-Garcia R \& J Gómez-Gutierrez. 1996. Copepod community structure at Bahia Magdalena, Mexico during El Niño 1983-1984. Estuarine, Coastal and Shelf Sciences 43: 583-595.

Perissinotto R. 1992. Mesozooplankton size-selectivity and grazing impact on the phytoplankton community of the Prince Edward Archipelago (Southern Ocean). Marine Ecology Progress Series 79: 243-258.

Peterson CL. 1958. The physical oceanography of the Gulf of Nicoya, Costa Rica, a tropical estuary. Bulletin International American. Tropical Tuna Commission 3: 139-188.

Raymont J. 1980. Plankton and productivity in the oceans. I. Phytoplankton, 484 pp. Pergamon Press, Oxford.

Ryther JH. 1969. Photosynthesis and fish production in the sea. Science 166: 72-76.

Sautour B, F Artigas, A Herbland \& A Laborde. 1996. Zooplankton grazing impact in the plume of dilution of the Gironde estuary (France) prior to the spring bloom. Journal of Plankton Research 18: 835-853.

Sautour B, F Artigas, D Delmas, A Herbland \& L Laborde. 2000. Grazing impact of microzooplankton and mesozooplankton during a spring station in coastal waters off the Gironde estuary. Journal of Plankton Research 22: 531-552.

Smayda T. 1980. Phytoplankton species succession. In: Morris I (ed), The physiological ecology of phytoplankton, pp. 493-571. University of California Press, Berkeley.

Sterner R, J Elser \& D Hessen. 1992. Stoichiometric relationship among producers, consumers and nutrient cycling in pelagic ecosystems. Biogeochemie 17: 49-67.

Stolte W. 1996. Size-dependent restrictions on competition for nutrients by marine phytoplankton, $122 \mathrm{pp}$. Proefschrift. Rijks Universiteit Groningen, Amsterdam.

Strickland JD \& TR Parsons. 1972. A practical handbook of seawater analysis. Fisheries Research Board of Canada. Bulletin 167: 1-310.
Strom S \& NA Welschmeyer. 1991. Pigment-specific rates of phytoplankton growth and microzooplankton grazing in the open subartic Pacific Ocean. Limnology and Oceanography 36: 50-63.

Subrahmanyan R. 1946. A systematic account of the Madras coast. Proceedings of the Indian Academy of Sciences 24(4B): 1-197.

Tomas C. 1993. Marine phytoplankton. 263 pp. Academic Press. San Diego.

Tomas C. 1996. Identifying marine diatoms and dinoflagellates, 597 pp. Academic Press, San Diego.

Tönnesson K, M Maar, C Vargas, EF Møller, S Satapoomin, S Zervoudaki, E Christou, A Giannakourou, A Sell, JK Petersen, TG Nielsen \& $\mathbf{P}$ Tiselius. 2005. Grazing impact of Oikopleura dioica and copepods on an autumn plankton community. Marine Biology Research 1: 365-373.

Turner J. 1984. The feeding ecology of some zooplankters that are important prey items of larval fish. NOAA Technical Report NMFS 7: 1-28.

Turner J \& JC Roff. 1993. Trophic levels and the trophospecies in marine plankton: lessons from the microbial food webs. Marine Microbial Food Webs 37: $225-248$

Utermöhl H. 1958. Zur Vervollkommnung der quantitativen Phytoplankton Methodik. Mitteilungen der Internationalen Vereinigung für Theoretische und Angewandte Limnologie, Stuttgart 9: 1-38.

Uye S. 1994. Replacement of large copepods by small ones with eutrophication of embayments: cause and consequence. Hydrobiologia 292/293: 513-519.

Vargas JA. 1995. The Gulf of Nicoya estuary, Costa Rica. Past, present and future cooperative research. Helgoländer Meeresuntersuchungen 49: 821-829.

Vargas JA. 1996. Ecological dynamics of a tropical intertidal mudflat community: In: Nordstrom KF \& CT Roman (eds), Estuarine Shores: Evolution, Environments and Human Alterations, pp. 355-371. John Wiley \& Sons Ltd., London.

Víquez R. 1983. Occurrence and distribution of planktonic diatoms in the Gulf of Nicoya, Costa Rica. M Sc. Thesis in Botany, University of Rhode Island, $89 \mathrm{pp}$.

von Wangelin M \& M Wolff. 1996. Comparative biomass spectra and species composition of the zooplankton communities in Golfo Dulce and Golfo de Nicoya, Pacific coast of Costa Rica. Revista de Biología Tropical 44 (Suppl.3): 135-156.

Voorhis AD, CE Epifanio, D Maurer, AI Dittel \& JA Vargas. 1983. The estuarine character of the Gulf of Nicoya, an embayment on the Pacific coast of Central America. Hydrobiologia 99: 225-237. 
Walter T. 1989. Review of the new world species Pseudodiaptomus (Copepoda: Calanoida), with a key to the species. Bulletin of Marine Science 45: 590-628.

Welschmeyer NA \& CJ Lorenzen. 1985. Chlorophyll budgets, zooplankton grazing and phytoplankton growth in a temperate fjord and the Central Pacific gyres. Limnology and Oceanography 30: 1-21.

White JR \& M Roman. 1992. Seasonal study of metazoan zooplankton in the mesohaline Chesapeake Bay. Marine Ecology Progress Series 86: 251-261.
Wiafe G \& Ch Leslie. 1996. Short-term temporal variation in coastal zooplankton communities: the relative importance of physical and biological mechanisms. Journal of Plankton Research 18: 1485-1501.

Zar J. 1996. Biostatistical analysis. 662 pp. Prentice-Hall, New Jersey.

Zhang X, HG Dam, JR White \& MR Roman. 1995. Latitudinal variations in mesozooplankton grazing and metabolism in the central tropical Pacific during the U.S. JGOFS EqPac study. Deep-Sea Research 42: 695-715.

Recibido el 1 de marzo de 2007 y aceptado el 18 de enero de 2008 